\title{
NEW ENCHYTRAEID SPECIES \\ (OLIGOCHAETA: ENCHYTRAEIDAE) FROM THE DANUBE-DRÁVA NATIONAL PARK
}

\author{
Klára Dózsa-Farkas ${ }^{1}$, Adrienne Ortmann-Ajkai ${ }^{2}$ and Ferenc Horváth ${ }^{3}$ \\ ${ }^{1}$ Eötvös Loránd University, Department of Systematic Zoology and Ecology \\ H-1117 Budapest, Pázmány Péter sétány 1/C, Hungary; E-mail: kdozsafarkas@gmail.com \\ ${ }^{2}$ University of Pécs, Department of Hidrobiology, H-7624 Pécs, Ifjúság u. 6. Hungary \\ E-mail:aadrienn@gamma.ttk.pte.hu \\ ${ }^{3}$ Hungarian Academy of Sciences, Centre for Ecological Research, Institute of Ecology and Botany \\ H-2163 Vácrátót, Alkotmány u. 2-4; E-mail: horvath.ferenc@okologia.mta.hu
}

The enchytraeid fauna of the Dráva Floodplain (Bükkhát Forest Reserve, alder swamp and meadows at Kisszentmárton, and Barcs Nature Conservation Area belonging to the Danube-Dráva National Park, Hungary) was investigated for the first time. A total of 14 enchytraeid genera, including 49 species and two other annelid worms (Hrabeiella periglandulata and Rhyacodrilus falciformis) were identified. Four species: Fridericia connatiformis sp. n., F. phaeostriata sp. n., F. longiducta sp. n. and Cernosvitoviella buekkhati sp. n. are new to science and described in this paper.

Key words: Fridericia, Cernosvitoviella, new species, Enchytraeidae, Clitellata, Annelida, fauna, Danube-Dráva National Park.

\section{INTRODUCTION}

Between 2011 and 2014 we investigated the Danube-Dráva National Park. In the present paper the faunistic results from this area and new enchytraeid species are presented.

\section{MATERIAL AND METHODS}

The Danube-Dráva National Park, founded in 1996, is located in the south-west of Hungary. Current area is 490 square kilometres and the majority of national park sites are located within the floodland areas of the Danube and Dráva rivers. The sampling sites were selected after a spatial analysis of the most natural and characteristic regional habitat records of the MÉTA database, produced by the Landscape Ecological Vegetation Mapping Project of Hungary (Molnár et al. 2007).

In the Danube-Dráva National Park sampling was made in the Dráva Floodplain, floodplain hardwood forests in Bükkhát Forest Reserve, and in an alder swamp at Kisszentmárton and in several meadows. Furthermore, secondary juniper shrublands were sampled in an adjacent area, the Barcs Nature Conservation Area.

The Dráva river constitutes the south-west border of Hungary. Its floodplain lies at an elevation of $90-110 \mathrm{~m}$ a.s.l.; the coordinates (centre) are $45^{\circ} 52^{\prime} \mathrm{N} ; 18^{\circ} 00^{\prime} \mathrm{E}$. The climate is moderately warm to moderately wet, mean annual temperature is $10.4^{\circ} \mathrm{C}$, and mean an- 
nual precipitation is between 730 and $760 \mathrm{~mm}$, with summer drought periods occasionally up to two months. Soils are Histosols and Luvisols (FAO-UNESCO 1997). The groundwater table is at 2-4 m (DövÉNYI 2010). Depressions (former watercourse beds) are covered by water in spring for three to six weeks. Dominant near-natural phytosociological associations, where sampling was made, are hornbeam-pedunculate oak forests (Circaeo-Carpinetum Borhidi \& Kevey 2006), and oak-ash-elm hardwood alluvial forests with Quercus robur, Fraxinus angustifolia and Ulmus laevis (Carici brizoidis-Ulmetum Kevey 2008), alder swamps (Carici elongatae-Alnetum), and different associations of wet meadows (ORTMANNAjKaI \& HoRváth 2010). For a more detailed description of the Bükkhát Forest Reserve and Kisszentmárton sites see also Ortmann-AjKai 1997, 1998, Ortmann-AjKAi et al. 2012 for Barcs Nature Conservation area (JuHÁsz et al. 1985).

All sampled habitats belong to natural habitats of European Community importance (NATURA 2000 habitats), listed as "Illyrian oak-hornbeam forests (Erythronio-Carpinion; 91L0)"; "Riparian mixed forests of Quercus robur, Ulmus laevis and Ulmus minor, Fraxinus excelsior or Fraxinus angustifolia, along the great rivers (Ulmenion minoris; 91F0)"; "Alluvial forests with Alnus glutinosa (Alno-Padion)", etc; 91E0); "Alluvial meadows of river valleys of the Cnidion dubii; 6440)"; "Lowland hay meadows (Alopecurus pratensis, Sanguisorba officinalis, 6510)"; and "Juniperus communis formations on heaths or calcareous grasslands 5130)", accordingly (European Commission 2007).

Collecting sites - In total, 12 localities 17 macro- and microhabitats were sampled (Appendix).

The animals were extracted from the soil by the wet funnel method ( $\left.\mathrm{O}^{\prime} \mathrm{CoNNOR} 1962\right)$.

Worms were first observed and measured alive, than anaesthetized in $20-30 \%$ ethanol and subsequently preserved in $70 \%$ ethanol. Later, the adult specimens of the new species were stained with borax-carmine, then passed through an ethanol (70\% to absolute) dehydration series, mounted temporarily in clove oil, and later mounted in Euparal in a slide between two cover slips. The important morphological structures in vivo were recorded, drawn and photographed using Axio Imager.A2 microscope, using DIC (differential interference contrast) illumination and an AxioCam MRc 5 (Zeiss) digital camera with Axiovision software. The whole mounted specimens were reinvestigated and photographed, too.

Holotypes and paratypes of new taxa are deposited in the collection of the Department of Systematic Zoology and Ecology, Eötvös Loránd University, Budapest.

\section{RESULTS}

In total 49 species were recorded, belonging to 14 enchytraeid genera (Table 1). Four species are considered new to science and described below: Fridericia connatiformis sp. n., F. longiducta, F. phaeostriata and Cernosvitoviella buekkhati sp. n. Moreover, a terrestrial polychaete (Hrabeiella periglandulata) and a terrestrial tubificid (Rhyacodrilus falciformis) were also found. All species represent new records for the Dráva Plain. The status of one Achaeta, one Enchytronia species have not been ascertained yet. These probably represent new species for science, but further investigations are needed to clarify their status. A list of species collected in the individual samples is given in the Appendix. 
Table 1. A list of the enchytraeid and two other annelid species of the Duna-Dráva National Park.

\begin{tabular}{|c|c|}
\hline Achaeta affinis Nielsen et Christensen, 1959 & Fridericia dura (Eisen, 1879) (=F. ratzeli \\
\hline Achaeta eiseni Vejdovsky, 1878 & Dózsa-Farkas, 2005) \\
\hline Achaeta pannonica Graefe, 1989 & Fridericia galba (Hoffm.,1843) (/1=with 2-4 \\
\hline Achaeta sp. & diverticula, $/ 2=$ with $5-8$ diverticula) \\
\hline Bryodrilus ehlersi Ude, 1892 & Fridericia isseli Rota, 1994 \\
\hline Buchcholzia appendiculata (Buchholz, 1862) & Fridericia lacii Dózsa-Farkas, 2009 \\
\hline Buchcholzia fallax Michelsen, 1887 & Fridericia nemoralis Nurminen, 1970 \\
\hline Cernosvitoviella buekkhati sp. $\mathrm{n}$. & Fridericia paroniana Issel,1 904 \\
\hline -Farkas, 1990 & Fridericia \\
\hline Chamae & Fridericia \\
\hline & (sensu F.eiseni \\
\hline Chamaedrilus & Dóz \\
\hline 1878 & Fridericia schmelzi Cech \& Dózsa-Farkas, \\
\hline Enchytraeus buchcholzi Vejdovsk & 2005 \\
\hline & Fridericia sohlenii Rota, Healy et Erséus, \\
\hline ulbosus Nielsen et Christens- & 1998 \\
\hline $\begin{array}{r}\text { en } \\
\text { Enchytra }\end{array}$ & $\begin{array}{l}\text { Fridericia miraflores Sesma et Dózsa-Farkas, } \\
1993\end{array}$ \\
\hline atus Nielsen & Globulidrilu: \\
\hline & $\begin{array}{l}\text { ricia parva Nielsen et Christensen, } \\
9\end{array}$ \\
\hline $\begin{array}{l}\text { Enchytraeus lacteus Nielsen et Christens } \\
\qquad 1961\end{array}$ & 9 \\
\hline Enchytronia baloghi Dózs & Henlea $p$ \\
\hline Enchytron & Henlea ver \\
\hline $\begin{array}{l}\text { Enchytronia parva Nielsen \& Christensen, } \\
1959\end{array}$ & $\begin{array}{l}\text { Marionina argentea (Michelsen, 1889) sensu } \\
\text { lato }\end{array}$ \\
\hline Enchyt & Marionina communis Nielsen et Christens- \\
\hline Fri & \\
\hline Fridericia benti Schmelz, 2003 & Marionina simillima Nielsen et Christensen \\
\hline Fridericia bisetosa (Levinsen, 18 & 1959 \\
\hline Fridericia bulboides Nielsen \& Christensen, & pelicensis Issel, 1905 \\
\hline & \\
\hline cher, 1902 & Rhyacodrilus falciformis Bretscher, 1901 \\
\hline Fride & Hrabeiella periglandulata Pižl et Chalupský, \\
\hline Fridericia deformis Möller, 1971 & 1984 \\
\hline
\end{tabular}

\section{DESCRIPTION OF THE NEW SPECIES}

\section{Fridericia connatiformis Dózsa-Farkas, sp. n. (Figs 1A-D, 2-4)}

Type material - Holotype: F.22. slide No. 721. Type locality: Páprád, Bükkhát Forest Reserve, Danube-Dráva National Park, 4552'19.4"N, $18^{\circ} 00^{\prime} 47.4^{\prime \prime} \mathrm{E}, 109 \mathrm{~m}$ a.s.l., riverine oak-elm-ash woodlands, leg. Ortmann-Ajkai, A., 08. 11. 2012. 
Paratypes (in total 15 specimens): P.99.1 slide No. 1142, one specimen from type locality leg. Dózsa-Farkas, K., Ortmann-Ajkai, A. \& Farkas, J., 28. 03. 2011; P. 99.2-99.8. slide No. $715,720,747,748,749,750,755$, seven specimens, from type locality, leg. Ortmann-Ajkai, A., 08. 11. 2012; P. 99.9. slide No. 746, from type locality, leg. Dózsa-Farkas, K., Farkas, J., 13. 11. 2013; P. 99.10. slide No. 740. One specimen, Bükkhát Forest Reserve, $45^{\circ} 52^{\prime} 35.2^{\prime \prime} \mathrm{N}$, $18^{\circ} 00^{\prime} 41.3^{\prime \prime} \mathrm{E}, 127 \mathrm{~m}$ a.s.l., lowland pedunculate oak-hornbeam woodlands under Ruscus aculeatus shrubs, leg. Dózsa-Farkas, K., Ortmann-Ajkai, A. \& Farkas, J., 28. 03. 2011; P. 99.11. slide No. 742. one specimen, between village Sellye and Bogácsa, $45^{\circ} 52^{\prime} 24.6^{\prime \prime} \mathrm{N}$, $17^{\circ} 48^{\prime} 01.1^{\prime \prime} \mathrm{E}, 104 \mathrm{~m}$ a.s.l., meadow with young Quercus plantation, leg. Dózsa-Farkas, K., Ortmann-Ajkai, A. \& Farkas, J., 28. 03. 2011; P. 99.12 slide No. 583 one specimen, Tivadar, $48^{\circ} 03^{\prime} 48^{\prime \prime} \mathrm{N}, 2^{\circ} 31^{\prime} 18^{\prime \prime} \mathrm{E}, 108 \mathrm{~m}$ a.s.l., meadow near Tisza river, leg. Dózsa-Farkas, K. \& Farkas, J., 8. 10. 2000; P. 99.13 slide No. 719 one specimen, Markaz, Mátra Mts, 47050'47" N, $20^{\circ} 03^{\prime} 08^{\prime \prime}$ E, $450 \mathrm{~m}$ a.s.l., oak woodland, leg. Dózsa-Farkas, K. \& Farkas, J., 31. 03. 2003; P.

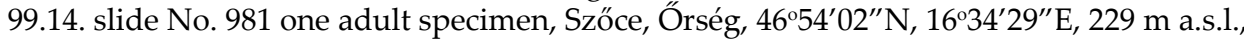
sphagnum bog, leg. Dózsa-Farkas, K., Farkas, J., Tóth, Z. \& Hock, F., 31. 03. 2014; P. 99.15. slide No. 984 one adult specimen, Szentgyörgyvölgy, Örség, 464ㄴ $14^{\prime \prime} \mathrm{N}, 16^{\circ} 25^{\prime} 01^{\prime \prime} \mathrm{E}, 238 \mathrm{~m}$ a.s.l., hayfield, leg. Dózsa-Farkas, K., Farkas, J., Tóth, Z. \& Hock, F., 31. 03. 2014.

Etymology - Named after its similarity with F. connata.

Diagnosis - The new species can be recognized by the main following combination of characters: (1) large size (15-23 mm in vivo), segments 45-65; (2) two chaetae (rarely one) per bundle; (3) body wall thick; (4) five preclitellar nephridia; (5) coelomo-mucocytes c/b type, lenticytes small; (6) clitellum saddle-shaped, hyalocytes and granulocytes arranged in transverse rows dorsally; (7) bursal slit T-shaped; (8) large seminal vesicle; (9) sperm funnel cylindrical, approximately 3-4 times as long as wide in vivo, (2-3 times when fixed), collar as wide as the funnel body, sperm ca $500 \mu \mathrm{m}$ long; (10) subneural gland present in XIII and XIV; (11) the most important characteristic feature, apart from the subneural glands, large extra sexual glands in $4 / 5$ and in XI, (rarely in VII and XIII); (12) spermathecae separate entally, ampullae wide, with two large diverticula on short stalks.

Description - Large worm, holotype $13.1 \mathrm{~mm}$ long, $690 \mu \mathrm{m}$ wide at VIII and $710 \mu \mathrm{m}$ at the clitellum (fixed), segments 66. Body length of paratypes 14-23 mm, width 450-540 $\mu \mathrm{m}$ at VIII and 570-700 $\mu \mathrm{m}$ at the clitellum (in vivo), length of fixed specimens 11.4-19.9 $\mathrm{mm}$, width $470-690 \mu \mathrm{m}$ at VIII, 530-710 $\mu \mathrm{m}$ at the clitellum, segments $48-66$. Chaetae two per bundle throughout, occasionally 1 , formula: $(1), 2-2,(1): 2-2$. Length of chaetae about 55-60 $\mu \mathrm{m}$, diameter $6.5-7 \mu \mathrm{m}$ preclitellarly and $60-70 \times 6.5-8 \mu \mathrm{m}$ postclitellarly. Detached chaetae often present in coelom. Head pore at $0 /$ I. Dorsal pores from VII. Light brown epidermal gland cells arranged in 2-3 transverse rows per segments (Fig. 3A). Body wall thick, about 45-50 $\mu \mathrm{m}$, cuticle about $3 \mu \mathrm{m}$ ). Clitellum in XII-1/2XIII saddle-shaped, the hyaline and granular gland cells arranged in dense transverse rows dorsally (Figs 2A-B). Brain (Fig. 1A) egg-shaped, about 2-2.5 times longer than wide (about 180-200 $\mu \mathrm{m}$ long). Oesophageal appendages (peptonephridia) (Fig. 1D) long with wide lumen and with 3-5 terminal branches. Pharyngeal glands all united dorsally, all with ventral lobes. Chloragocytes from V, dark brown (in vivo). Dorsal blood vessel from XIX-XXI, blood colourless. Five pairs of preclitellar nephridia from 6/7 to 10/11. Coelomo-mucocytes (length 40-57 
$\mu \mathrm{m}$ in vivo) type $\mathrm{c} / \mathrm{b}$ (according to MöLler 1971), fine granular matrix and clearly visible nucleus, sometimes with a few refractile vesicle, lenticytes small (3-5 $\mu \mathrm{m}$ long) and scarce (Figs 2C-D). Chylus cells between XVI-XVIII, occupying three segments. Seminal vesicle large in X-XI. Sperm funnels (Figs 1B, 2E) cylindrical, 3-4 times as long as wide, about $500-600 \mu \mathrm{m}$ long (in vivo). In fixed specimens the length of funnels are $225-400 \mu \mathrm{m}$. Collar as wide as funnel body. Spermatozoa about 350-500 $\mu \mathrm{m}$ long, heads 120-130 $\mu \mathrm{m}$ (in vivo). Vas deferens 8-9 $\mu \mathrm{m}$ wide. Male copulatory organs (Fig. 2F) on average $156 \mu \mathrm{m}$ long, 84 $\mu \mathrm{m}$ wide and $67 \mu \mathrm{m}$ high, bursal slit T-shaped (Fig. $2 \mathrm{H}$ ). Well-developed subneural glands in XIII-XIV (Fig. 2G). Characteristic extra sexual glands (copulatory glands) at $4 / 5$ near the

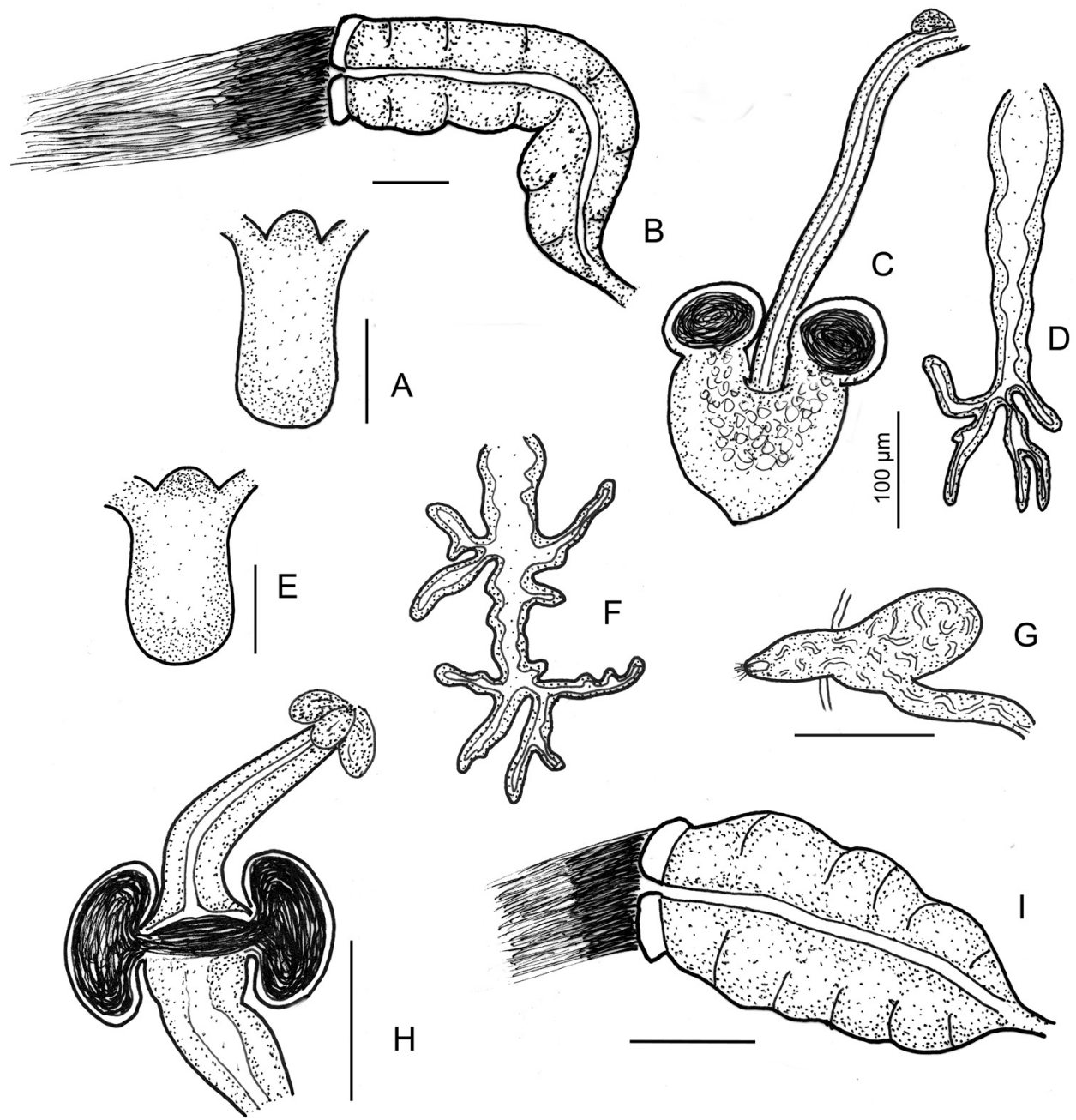

Fig. 1. Fridericia connatiformis sp. $n$. $A=$ brain, $B=$ sperm funnel, $C=$ spermatheca, $D=$ oesophageal appendage. E-I: Fridericia phaeostriata sp. n., E = brain, $\mathrm{F}=$ oesophageal appendage, $\mathrm{G}=$ nephridium, $\mathrm{H}$ = spermatheca, $\mathrm{I}=$ sperm funnel (all figures were made from living specimens, scale bares $=100 \mu \mathrm{m}$ ) 
spermathecal orifice, round (diameter about 90-100 $\mu \mathrm{m}$, fixed) mostly on one side only, laterally (Figs 3A-B), and one oval gland in XI mid-ventrally (145-175 × 80-120 $\mu \mathrm{m}$, fixed) (Figs 2F, 3C). In one case gland in VII instead of at 4/5 (slide No. 742). Sometimes in XIII also one oval gland $(150-176 \times 90 \mu \mathrm{m}$, fixed) just before the subneural gland of XIII. Spermatheca (Figs 3D-H): ectal ducts as long as body diameter (about 300-450 $\mu \mathrm{m}$ long and 24-25 $\mu \mathrm{m}$ wide, the canals wide $(6 \mu \mathrm{m})$ in vivo, ducts $250-330 \mu \mathrm{m}$ long and 20-26 $\mu \mathrm{m}$ wide in fixed specimens. One small sessile (ca $25 \mu \mathrm{m}$ long) gland at the orifice of the spermath-
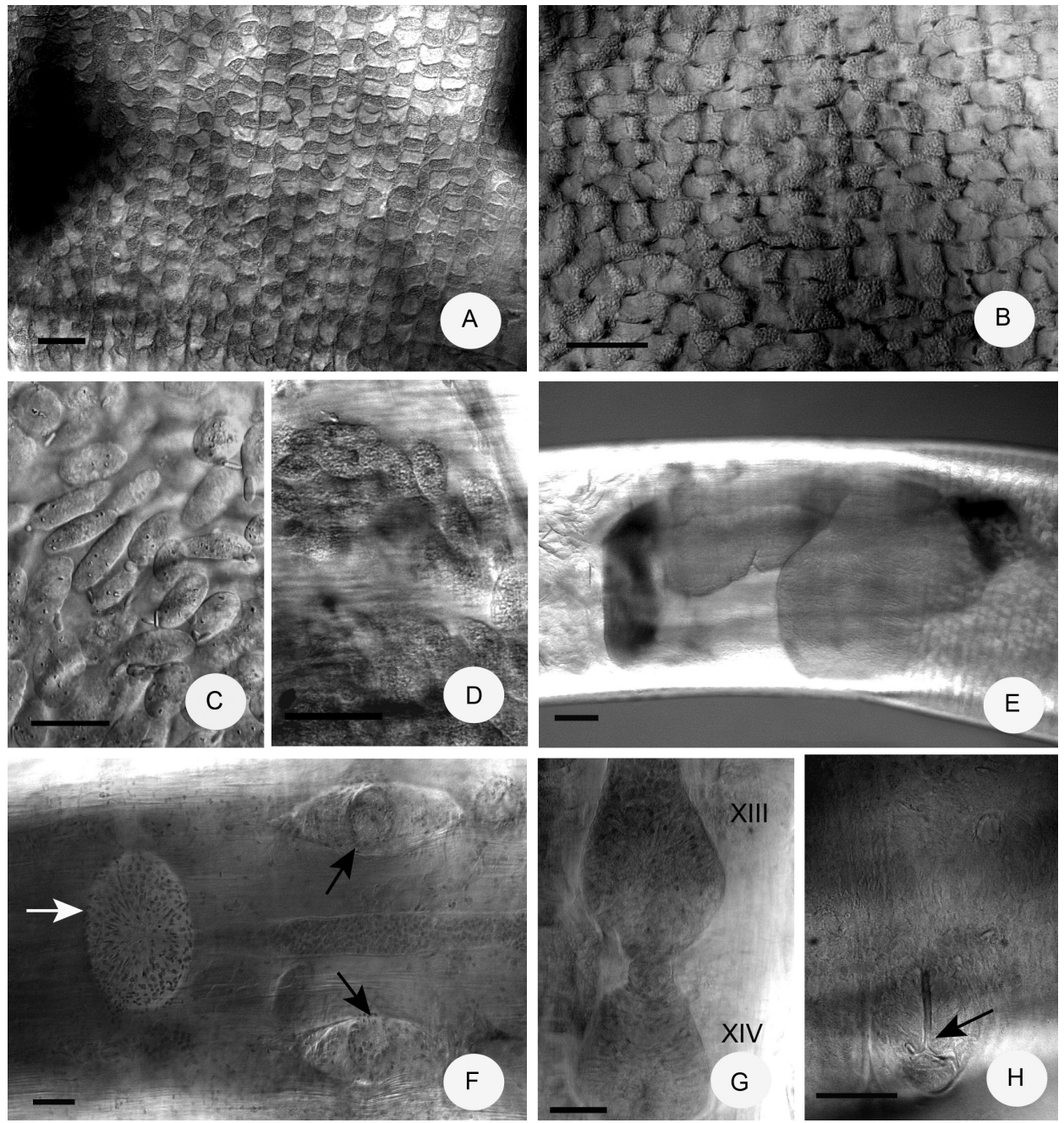

Fig. 2. Micrograph of Fridericia connatiformis sp. n: A-B = clitellar gland cells dorsally, C-D = coelomocytes, $\mathrm{E}=$ sperm funnels, $\mathrm{F}=\mathrm{XI}-\mathrm{XII}$ ventrally (extra sexual gland marked with white arrow, male copulatory organs marked with black arrows), $G=$ subneural glands in XIII and XIV , H = bursal slit marked with arrow. (A, C, E, H in vivo, B, D, F, G fixed, stained; scale bars $=50 \mu \mathrm{m}$ ) 
ecal ducts. Duct projecting into ampulla without ental bulb. Ampulla mostly as long as wide, about 140-170 $\mu \mathrm{m}$ wide (fixed), thick-walled, containing fine pale granules, tapering proximad, no separation into distal and proximal part. Ampullar lumen not " $U$ " form. The communication of the ampullae with the oesophagus is separate. Two spherical diverticula with short stalks, thin-walled (diameter 75-110 $\mu \mathrm{m}$ in vivo and 70-105 $\mu \mathrm{m}$, fixed), mostly filled with brown sperm (in transmitted light) sperm not rotating, diverticula sometimes empty. One or two mature eggs at a time.
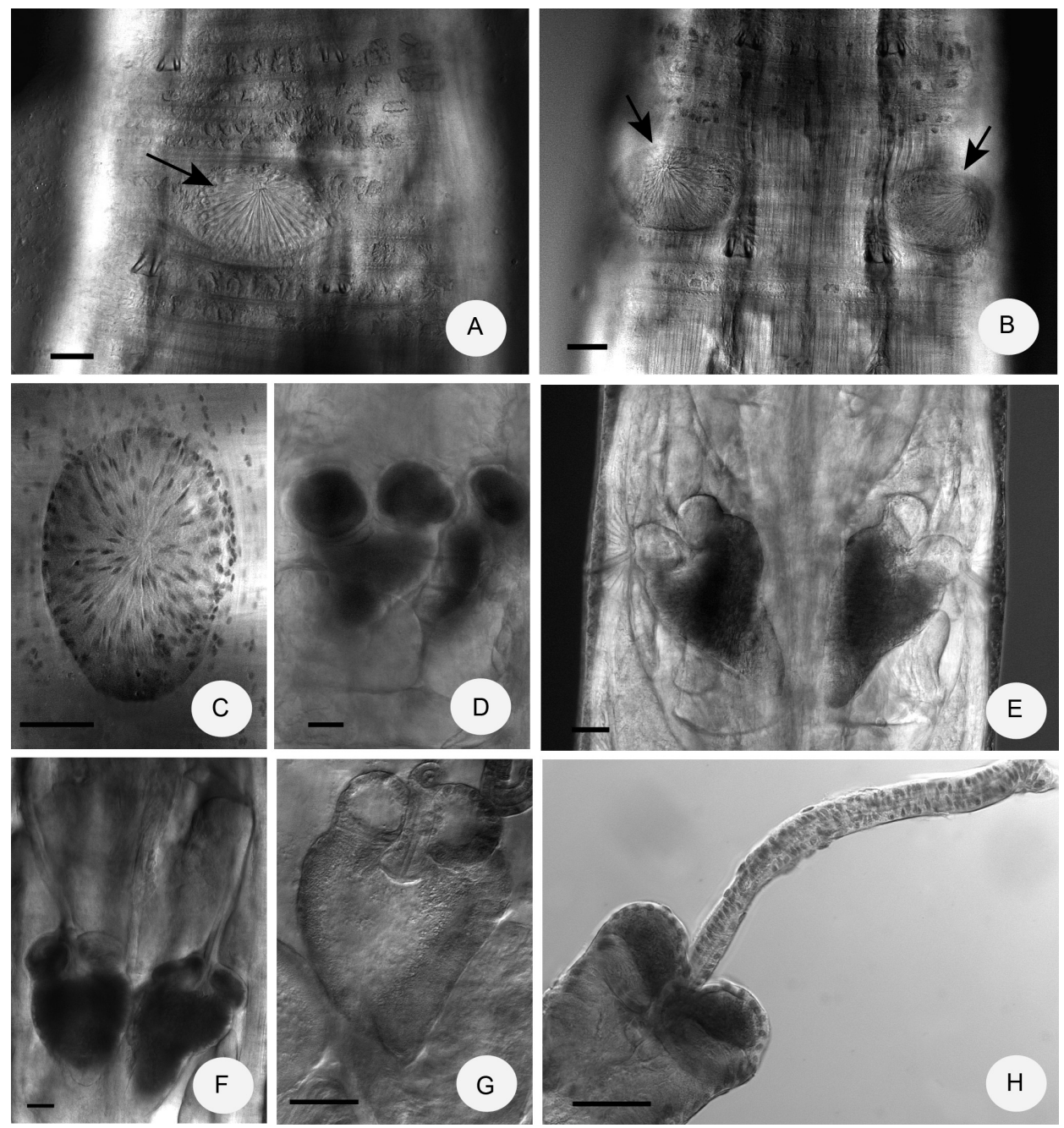

Fig. 3. Micrograph of Fridericia connatiformis sp. n.: $\mathrm{A}=$ epidermal glands in transverse rows and an extra sexual gland in $\mathrm{V}$ (marked with arrow), $\mathrm{B}=$ two extra sexual glands in $\mathrm{V}$ (marked with arrows), $\mathrm{C}=$ extra sexual glands in XI ventrally, D-H spermathecae (in $\mathrm{D}, \mathrm{F}$ and $\mathrm{H}$ the diverticula full with sperm, in $\mathrm{E}$ and $\mathrm{G}$ the diverticula empty). (A, B, D-F in vivo, C, G fixed, stained, $\mathrm{H}$ one removed spermatheca of the fixed, stained specimens; scale bars $=50 \mu \mathrm{m}$ ) 

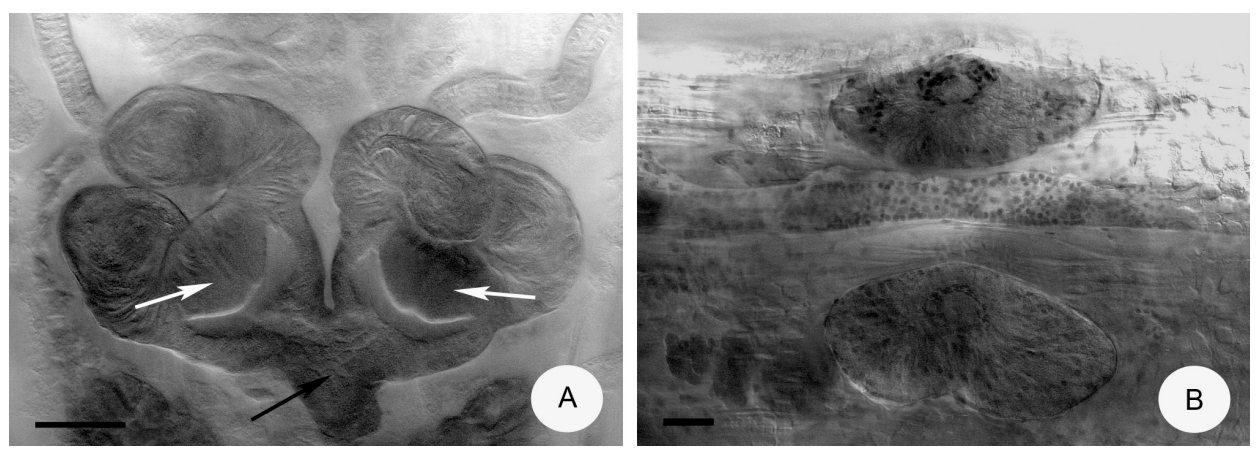

Fig. 4. Micrograph of Fridericia connata (conspicuous differences between this species and F. connatiformes): $\mathrm{A}=$ spermathecae: the proximal parts of the two spermathecal ampullae fused marked with black arrow, and the large ental bulbs marked with white arrows), $\mathrm{B}=$ larger male copulatory organs. (A-B, stained specimens; scale bars $=50 \mu \mathrm{m}$ )

Distribution and habitat - Dráva Floodplain, Danube-Dráva National Park, Páprád, Bükkhát Forest Reserve, riverine oak-elm-ash woodlands, $45^{\circ} 52^{\prime} 19.4^{\prime \prime} \mathrm{N}, 18^{\circ} 00^{\prime} 47.4^{\prime \prime} \mathrm{E}, 109$ $\mathrm{m}$ asl; near Tisza River, Tivadar, $48^{\circ} 03^{\prime} 48^{\prime \prime} \mathrm{N}, 2^{\circ} 31^{\prime} 18^{\prime \prime} \mathrm{E}, 108 \mathrm{~m}$ a.s.l., meadow; Mátra Mts,

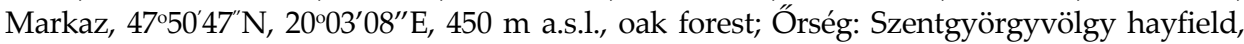
$46^{\circ} 45^{\prime} 14^{\prime \prime} \mathrm{N}, 16^{\circ} 25^{\prime} 01^{\prime \prime} \mathrm{E}, 238 \mathrm{~m}$ a.s.l.; Szöce, sphagnum bog, 46 $54^{\prime} 02^{\prime \prime} \mathrm{N}, 16^{\circ} 34^{\prime} 29^{\prime \prime} \mathrm{E}, 229 \mathrm{~m}$ a.s.l.

Differential diagnosis - Dózsa-Farkas (2009) classified the Fridericia species with two spermathecal diverticula in groups. In group II.1., the spermathecal diverticula are globular or hemispherical, sessile or with short stalks (11 species) (Dózsa-Farkas 2009, table 3, 4). Only three species of this group have only two chaetae in the chaetal bundles: Fridericia cylindrica Springett, 1971, Fridericia sohleni Rota, Healy et Erséus, 1998, and Fridericia bisetosa (Levinsen, 1884). All three species are smaller (10-15 mm long) than the new species, subneural glands absent, the sperm funnels also smaller and only 1.5-2× as long as wide. Moreover in the first two species the collar is narrower, and the mucocytes are of the b-type. Most similar to the new species is F. bisetosa but the spermathecal ampullae of the new species differs in shape and size and the diverticula are much larger (Schmelz 2003). The new species is also similar to two species of group I.1, with 'The proximal part of the two spermathecal ampulla fused, one common opening into oesophagus' (Dózsa-FARKAs 2009), F. connata Bretscher, 1902 and F. brunensis Schlaghamerskỳ, 2008. F. connata is similar to the new species in size, in the number of chaetae (also not more than two in the bundles), in the thick preclitellar septa and somewhat in the shape of the spermathecae, but the stalks of the spermathecal diverticula are longer and with a characteristic bend towards the ectal duct, the diverticular lumen is semicircular in top view, and the ampullar lumen forms a " $\mathrm{U}$ " around the 
bulbiform ental bulb of the ectal ducts (Fig. 4A). Moreover in F. connata the two spermathecal ampullae are fused, with one common opening into the oesophagus, and the male copulatory organs larger (Fig. 4B). F. connata (after own observations in Hungarian populations) mostly has yellow-green coelomocytes, c-type with some refractile granules. F. brunensis have only 1 chaeta regularly in posterior lateral bundles, have two spermathecal diverticula, but the two spermathecal ampullae fused and the chylus cells in IX-XI praeclitellarly (Schmelz 2003, Bretscher 1902, Schlaghamerský 2008). Only F. galba has similar "accessory sexual glands" (Schmelz 2003, p. 54), but this species based on the shape of his spermatheca and the number of chaetae in bundles cannot be confused with F. connatiformis. The F. connatiformis differs from all Fridericia species by the presence of extra sexual glands and subneural glands, it is an unique combination and also unusual that such a large Fridericia species has pharyngeal glands all united dorsally (Schmelz 2003).

\section{Fridericia phaeostriata Dózsa-Farkas, sp. n.}

(Figs 1E-I, 5-6)

Type material - Holotype: F.23 slide No. 1184, adult whole mount specimens. Type locality: Páprád, Bükkhát Forest Reserve, Danube-Dráva National Park, 4552'19.4"N, $18^{\circ} 00^{\prime} 47.4^{\prime \prime} \mathrm{E}, 109 \mathrm{~m}$ a.s.l., riverine oak-elm-ash woodlands, deeper humid area, leg. Ortmann-Ajkai, A. 20. 10. 2014.

Paratypes (in total 15 specimens): P.100.1-100.2. slide No. 1131, 1132, two specimens from type locality, leg. Ortmann-Ajkai, A., 08. 11 2012; P.100.3-100.8 slide No. 1139, 1140, 1192-1194, 1189) six specimens Páprád, Bükkhát Forest Reserve, 4552'19.4"N, $18^{\circ} 00^{\prime} 47.4^{\prime \prime} \mathrm{E}, 109 \mathrm{~m}$ a.s.l., deeper humid area, leg. Ortmann-Ajkai, A., 08. 11. 2012 and 20. 10. 2014; P.100.9. slide No. 1199 one specimen, Bükkhát Forest Reserve $45^{\circ} 52^{\prime} 15.2^{\prime \prime} \mathrm{N}$, $18^{\circ} 00^{\prime} 49.2^{\prime \prime} \mathrm{E}, 108 \mathrm{~m}$ a.s.l., lowland pedunculate oak-hornbeam woodlands, leg. DózsaFarkas, K. \& Farkas, J. 13. 11. 2013; P.100.10 slide No. 1196 one adult specimen Bükkhát Forest Reserve, $45^{\circ} 52^{\prime} 35.2^{\prime \prime} \mathrm{N}, 18^{\circ} 00^{\prime} 41.3^{\prime \prime} \mathrm{E}, 127 \mathrm{~m}$ a.s.l., in lowland pedunculate oak-hornbeam woodlands under Ruscus aculeatus shrubs, leg. Dózsa-Farkas, K., Ortmann-Ajkai, A. \& Farkas, J. 28. 03. 2011; P.100.11-100.13 slide No. 1133, 1134, 1136 three adult specimen,

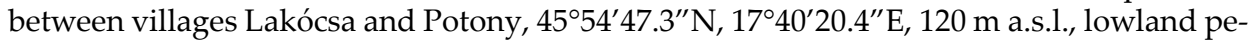
dunculate oak-hornbeam woodlands, leg. Dózsa-Farkas, K., Ortmann-Ajkai, A. \& Farkas, J., 28. 03. 2011; P.100.14-100.15 slide No.1137, 1138, two specimens Villányi Mts, Kistótfalu, $45^{\circ} 54^{\prime} 05^{\prime \prime} \mathrm{N}, 18^{\circ} 18^{\prime} 32^{\prime \prime}$ E, 119 m a.s.l., old oak woodland, leg. Dózsa-Farkas, K., Farkas, J. \& Boros, G. 04. 04. 2006; P.100.16-100.17. slide No. 1154, 1188. two adult specimens, Kőszeg Mts, $47^{\circ} 24^{\prime} 05.5^{\prime \prime} \mathrm{N}, 16^{\circ} 26^{\prime} 52.7^{\prime \prime} \mathrm{E}, 478 \mathrm{~m}$ a.s.l., ash-alder woodlands along a creek, leg. Dózsa-Farkas, K., Farkas, J., Tóth, Z., 21. 05. 2014 and 13. 10. 2014.

Deposited in the collection of the Department of Systematic Zoology and Ecology, Eötvös Loránd University, Budapest.

Etymology - Named after the dark epidermal glands in transverse rows; phaeo- = dark (Greek), striatus $=$ striped $($ Latin $)$. 
Diagnosis - The new species can be recognized by the following combination of characters: (1) large size (16-18 mm long and about $500 \mu \mathrm{m}$ wide, in vivo), cuticle thick, segments 50-62; (2) dark brown epidermal glands in conspicuous transverse rows in vivo; (3) maximum of 6 chaetae per bundle; (4) clitellum girdle-shaped: hyalocytes and granulocytes arranged in transverse rows dorsally, between the bursal slits only granulocytes; (5) five pairs of pre-
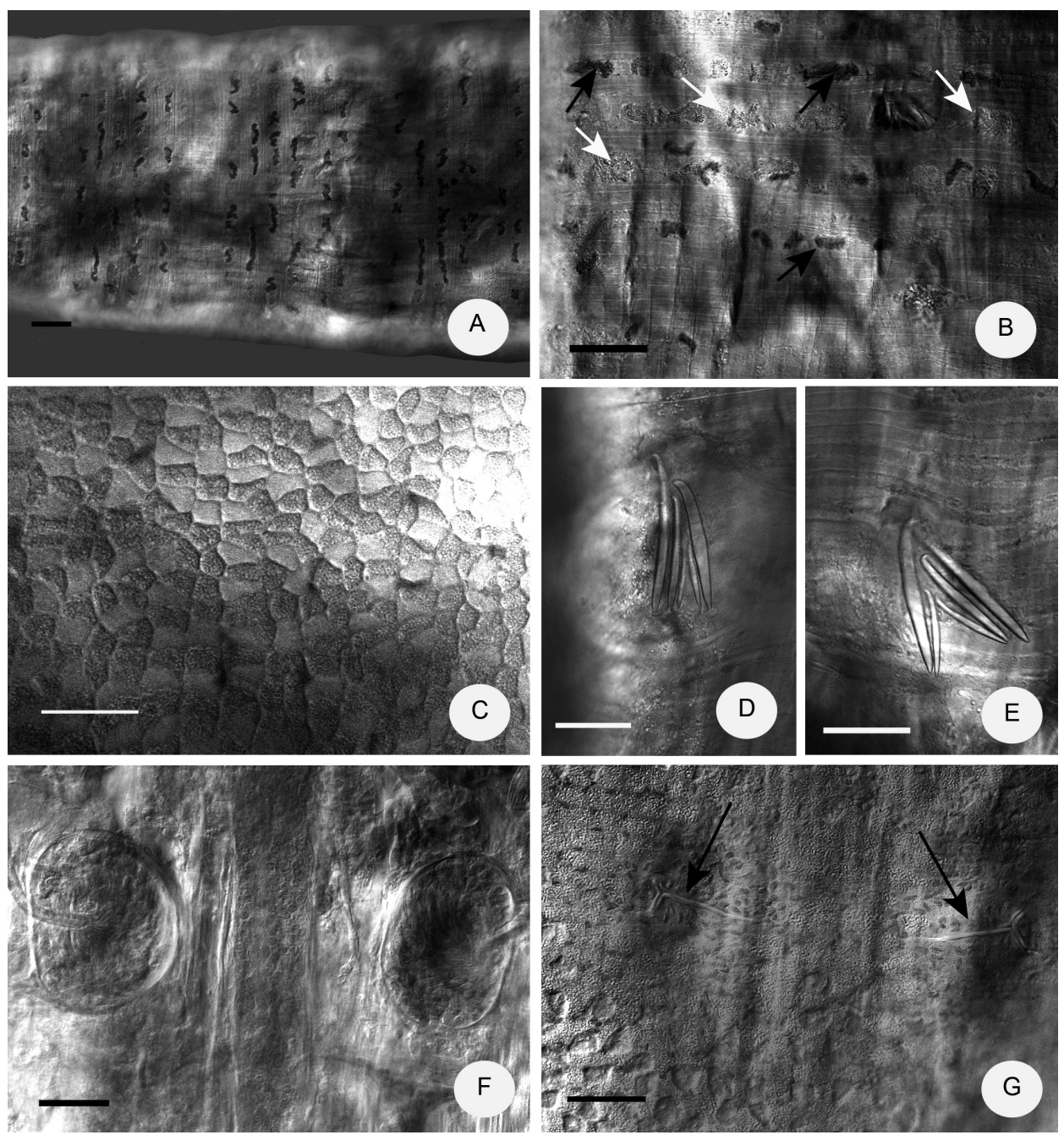

Fig. 5. Micrograph of Fridericia phaeostriata sp. n.: A = dusky epidermal gland in transversal rows, $\mathrm{B}=$ dusky epidermal glands (marked with black arrows) and clear gland cells (marked with white arrows), $\mathrm{C}=$ clitellar gland cells dorsally, $\mathrm{D}-\mathrm{E}=$ chaetae in bundles, $\mathrm{F}=$ male copulatory organs, $\mathrm{G}=$ bursal slits (marked with arrows). (A-E in vivo, F-G stained specimens; scale bars $=50 \mu \mathrm{m})$ 
clitellar nephridia; (6) mucocytes type a/b, lenticytes medium-large; (7) bursal slit Y-shaped; (8) large seminal vesicle; (9) two weekly developed subneural glands in XIII, XIV; (10) sperm funnel cylindrical, 2 times as long as broad, approximately half as long as body diameter; sperm about 200-290 $\mu \mathrm{m}$ long, head 40-60 $\mu \mathrm{m}$ long with intensive red-brown colour in vivo; (11) spermathecae separate entally; two large ear-shaped diverticula; ectal duct short and much widening proximad with 2-3 glands at the ectal orifice.
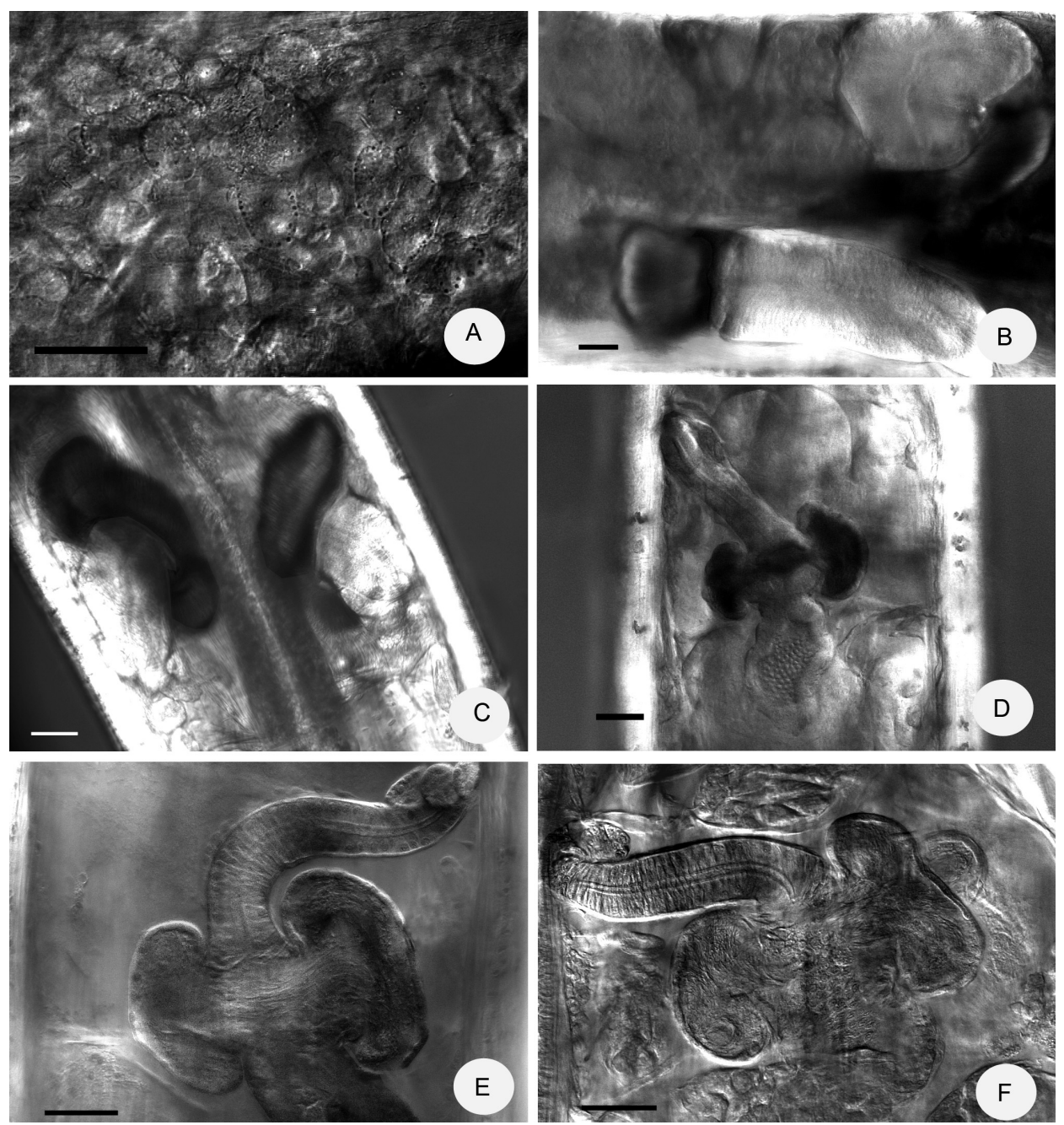

Fig. 6. Micrograph of Fridericia phaeostriata sp. n.: A = coelomocytes, B-C = sperm funnels ( $\mathrm{C}$ in some specimens the collar wider and the brash of sperm wider), $\mathrm{D}-\mathrm{F}=$ spermathecae (A-D in vivo, E-F fixed, stained; scale bars $=50 \mu \mathrm{m}$ ) 
Description - Holotype $9.4 \mathrm{~mm}$ long, $510 \mu \mathrm{m}$ wide at VIII and $520 \mu \mathrm{m}$ at clitellum (fixed), segments 58. Body length of paratypes 16-18 mm, width $410-490 \mu \mathrm{m}$ at VIII and $450-530 \mu \mathrm{m}$ at the clitellum (in vivo), length of fixed specimens $9.5-15 \mathrm{~mm}$ width 510 $600 \mu \mathrm{m}$ at VIII, 510-600 $\mu \mathrm{m}$ at the clitellum, segments 50-62. Chaetae: 3,4,5-4,3,2:4,5,6 $-4,(5) 3,2$. The chaetae within a bundle mostly not arranged in pairs (Figs 5D-E); in preclitellar bundles of five largest outer chaetae $70 \times 7 \mu \mathrm{m}$, smaller chaetae 60-62 $\times 7 \mu \mathrm{m}$ and the two innermost chaetae much smaller, $35 \times 3-4 \mu \mathrm{m}$. In postclitellar segments chaetae somewhat larger, e.g.: outer $100 \times 8-9 \mu \mathrm{m}$, two chaetae 87-88 $\times 8-9 \mu \mathrm{m}$ and the two inner chaetae 40-48 $\times$ 3-3.5 $\mu \mathrm{m}$ (Figs 5D-E) About from XXXII-XXXIV on (in some specimens earlier, from XXVI) only two equally long chaetae per bundle, size at the body end 100-120 $\times 10 \mu \mathrm{m}$. Head pore at 0/I. Dorsal pores from VII. $2-3$ rows hyaline epidermal gland cells arranged in transverse rows per segments and in addition about 5 transverse rows of very characteristic wavy, dark brown glands (visible only in vivo) (Figs 5A-B). Clitellum in XII$1 / 3 \mathrm{XIII}$, girdle-shaped, hyalocytes and granulocytes arranged in rows dorsally (diameter of cells 12-14 $\mu \mathrm{m}$ (Fig. 5C); only granulocytes between the bursal slits (Fig. 5G). Thickness of body wall about $60 \mu \mathrm{m}$, cuticle about $5 \mu \mathrm{m}$ in fixed specimens. Brain egg-shaped, about $125 \mu \mathrm{m}$ long (fixed), 1.5-2 times longer than wide (Fig. 1E).

Oesophageal appendages (peptonephridia) short, type c (Fig. 1F) First pair of pharyngeal glands with dorsal connection, second and third pair dorsally separate, all with ventral lobes. Chloragocytes from V, brown in vivo. Dorsal vessel from XIX-XXI, blood colourless. Midgut pars tumida not seen. Five pairs of preclitellar nephridia from 6/7 to 10/11, length ratio anteseptale: postseptale $1: 1.5-2$, midventral origin of efferent duct (Fig. 1G). Coelomo-mucocytes (Fig. 6A) length $20-40 \mu \mathrm{m}$, in vivo) slightly wavy in outline with retractile granules at periphery, type $\mathrm{a} / \mathrm{b}$, lenticytes 5-10 $\mu \mathrm{m}$ long. Chylus cells between XIVXVII, occupying 2 (3) segments. Seminal vesicle large in IX-XII, occupying 3 segments. Sperm funnels (Figs 1I, 6B-C) cylindrical, about 240-320 $\mu \mathrm{m}$ long and 100-160 $\mu \mathrm{m}$ wide (in vivo), about twice as long as wide, funnel length 200-300 $\mu \mathrm{m}$ in fixed specimens. Collar about as wide as the funnel, sometimes reclinate (Fig. 6C). Spermatozoa 200-250 $\mu \mathrm{m}$ long, heads as brown iridescent 'brush' on the top of sperm funnels, about 40-60 $\mu \mathrm{m}$ long (in vivo). Diameter of sperm ducts 7-10 $\mu \mathrm{m}$ (fixed). Male copulatory organs (Fig. 5F) 110-120 $\mu \mathrm{m}$ long, 80-100 $\mu \mathrm{m}$ wide and 60-75 $\mu \mathrm{m}$ high (fixed), the bursal slits y-shaped, the longer stem 40-50 $\mu \mathrm{m}$ long, the shorter stems 10-15 $\mu \mathrm{m}$ long (Fig. 5G). Subneural glands in XIIIXIV, mostly weakly developed, in XIII larger. Spermathecae (Figs 1H, 6D-F): mostly three ectal glands at the orifice, 40-75 $\mu \mathrm{m}$ long; ectal ducts short, about 150-200 $\mu \mathrm{m}$ long, 50-55 $\mu \mathrm{m}$ wide proximally, narrower near ectal orifice, here diameter only $18-25 \mu \mathrm{m}$ in fixed specimens; ectal duct proximally projecting into ampulla, canal 5-7 $\mu \mathrm{m}$ wide, tapering to 2.5-3 $\mu \mathrm{m}$ towards ectal orifice). Ampullae spherical (diameter 75-95 $\mu \mathrm{m}$ ) with two large ear-shaped, sessile, thin-walled diverticula. Sperm arranged mostly in ring inside distal part of ampulla, filling out lumen of diverticula, so that these are dark brown in transmitted light (Fig. 6D). The length of diverticula 90-120 $\mu \mathrm{m}$ in the fixed specimens. Ampullae open separately into oesophagus. One-two mature egg at a time.

Distribution and habitat - Known from four localities in Hungary: floodplain of Dráva river Bükkhát Forest Reserve and between villages Lakócsa and Potony of Danube-Dráva National Park, riverine oak-elm-ash woodlands and lowland pedunculate oakhornbeam woodlands, Köszeg Mts, ash-alder woodland along a creek, Villány Mts, oak woodland. 
Differential diagnosis - A very distinctive trait of the new species are dark brown epidermal glands in 4-5 transversal rows per segments. $4-5$ rows of colored epidermal gland found also in F. nemoralis Nurminen, 1970, but these are yellows. In F. maculata Issel, 1905 occure chacacteristic dark brown epidermal glands, but only one or two rows, and this species is smaller (Schmelz 2003). A similarly conical form of the spermathecal ectal duct found only in Fridericia humicola Bretscher, 1900 (Schmelz 2003), but in the latter the canal of the duct widens much proximally as well; in contrast, in F. phaeostriata sp. n. the canal has same diameter over its entire length, only at the ectal orifice it is narrower; besides, the shape of diverticula is different. Five Fridericia species have similar spermathecae with two ear- or bean-shaped and sessile spermathecal diverticula and a separate connection with the oesophagus (four of them listed in Dózsa-Farkas 2009, table 6): F. magna Friend, 1899; F. strenua Rota, 1995; F. auritoides Schmelz, 2003; F. aurita Issel, 1905 and F. longiducta sp. n. (see below). The main differences are as follows: F. aurita has a longer sperm funnel (as long as or longer than body diameter vs. about half as long as body diameter in the new species), spermatozoa much longer (ca $1000 \mu \mathrm{m}$ vs 200-250 $\mu \mathrm{m}$ ), no ectal gland at the spermathecal ectal orifice and the maximum number of chaetae four (Issel 1905). In F. auritoides the best characteristic feature are the additional ventral lobes of pharyngeal glands in VII, moreover the maximum number of chaetae 4 (5), vs 5-6 in the new species, and chylus cells in XVIII-XIX vs. XV-XVII, respectively (Schmelz 2003). F. strenua has more chaetae per bundle (8) and subneural glands are absent (RотA 1995). F. magna is longer (30-50 mm, 70-96 segments), the clitellum is saddle-shaped, and the blood is redish (FrIEND 1899). Finally, F. longiducta sp. n. differs from the F. phaeostriata sp. n. by its size (17-23.5 $\mathrm{mm}$ in vivo) and a very long spermathecal duct (longer than body diameter).

\section{Fridericia longiducta Dózsa-Farkas, sp. n.} (Figs 7-8)

Type material - Holotype: F.24 slide No. 1186 adult whole mount specimens. Type locality: Páprád, Bükkhát Forest Reserve, Danube-Dráva National Park, 45² $52^{\prime} 19.4^{\prime \prime} \mathrm{N}$, $18^{\circ} 00^{\prime} 47.4^{\prime \prime} \mathrm{E}, 109 \mathrm{~m}$ a.s.l., riverine oak-elm-ash woodlands, deeper humid area, leg. Ortmann-Ajkai, A. 20. 10. 2014.

Paratypes (in total 13 specimens): P.101.1-101.3. slide No. 1147, 1148, 1183, three specimens, Páprád, Bükkhát Forest Reserve, 4552'19.4" N, 1800'47.4"E, $109 \mathrm{~m}$ a.s.l., riverine oak-elm-ash woodlands, leg. Orthman-Ajkai, A. 08. 11. 2012; P. 101.4-101.11. slide No. 1141, 1144, 1145, 1161, 1172, 1178, 1179, 1190 eight adult specimens, Páprád, Bükkhát Forest Reserve, $45^{\circ} 52^{\prime} 19.4^{\prime \prime} \mathrm{N}, 18^{\circ} 00^{\prime} 47.4^{\prime \prime} \mathrm{E}, 109 \mathrm{~m}$ a.s.l., riverine oak-elm-ash woodlands, deeper humid area, leg. Orhman-Ajkai, A. 20. 10. 2014; P.101.12-101.13. slide No. 2000, 2001. two specimens, Kisszentmárton, alder and ash swamp woodlands, $45^{\circ} 49^{\prime} 18.6^{\prime \prime} \mathrm{N}, 18^{\circ} 01^{\prime} 09.3^{\prime \prime} \mathrm{E}$, 94 m a.s.l., leg. Dózsa-Farkas, K., Farkas, J. \& Boros, G. 28. 03. 2011. 
Deposited in the collection of Department of Systematic Zoology and Ecology, Eötvös Loránd University, Budapest.

Etymology - Named after the long spermathecal ectal duct.

Diagnosis - The new species can be recognized by the following combination of characters: (1) large size (17-23 mm long and about 530-700 $\mu \mathrm{m}$ wide in XII, in vivo), cuticle thick, segments 46-59; (2) max. 4 chaetae per bundle; clitellum girdle-shaped: hyalocytes and granulocytes arranged in transverse rows dorsally, between and around the bursal slits only granulocytes; (3) five preclitellar nephridia; (4) mucocytes type c, lenticytes medium-large; (5) chylus cells between XIII-XVII occupying 4-5 segments; (6) bursal slit Y-shaped; (7) large brown seminal vesicle, (8) subneural glands absent; (9) sperm funnel cylindrical, about half as long as body diameter, 1.5-2 times as long as broad, sperm long from $600 \mu \mathrm{m}$ up to $1000 \mu \mathrm{m}$, heads 70-110 $\mu \mathrm{m}$ long in vivo; (10) spermathecae separate entally, two large ear-shaped diverticula, ectal duct very long, with one gland at the ectal orifice.

Description - Holotype $15.9 \mathrm{~mm}$ long, $720 \mu \mathrm{m}$ wide at VIII and $770 \mu \mathrm{m}$ at clitellum (fixed), segments 51. Body length of paratypes 17-23 mm, width $440-620 \mu \mathrm{m}$ at VIII and 460-660 $\mu \mathrm{m}$ at clitellum (in vivo), length of fixed specimens $13-19 \mathrm{~mm}$ width $510-630 \mu \mathrm{m}$ at VIII, 530-700 $\mu \mathrm{m}$ at the clitellum, segments 46-59. Chaetae: 2,3,(4), - (4),3,1,2:4,3, - .4,3,1,2. The chaetae within a bundle are arranged in pairs; ventrally the outer chaetae $77-80 \times$ 6-7 $\mu \mathrm{m}$, the inner chaetae much smaller: $23-40 \times 2.5-3.5 \mu \mathrm{m}$ preclitellarly. In dorso-lateral bundles often only two chaetae per bundle but unequally long. Chaetae in the middle of body somewhat smaller, laterally often only one very small chaeta (25-30 $\mu \mathrm{m}$ long), more posteriorly two but unequally long chaetae. From about XXX-XXIV only two, but equally long chaetae, increasing in size caudad, up to $100-110 \times 10-11 \mu \mathrm{m}$. Head pore at 0/I. Dorsal pores from VII. 3-5 rows of hyaline epidermal gland cells per preclitellar segments (Fig. $8 \mathrm{C})$. Clitellum in XII-1/3XIII, girdle-shaped, hyalocytes and granulocytes arranged in indefinite rows dorsally (Fig. 8A), diameter of cells 20-25 $\mu \mathrm{m}$, only granulocytes around and between the bursal slits (Fig. 5B). Thickness of body wall about 50-80 $\mu \mathrm{m}$, cuticle about 5-6 $\mu \mathrm{m}$ in fixed specimens. Brain egg-shaped, about $160 \mu \mathrm{m}$ long (fixed), 1.5 times longer than wide (fixed) (Fig. 7A).

Oesophageal appendages (peptonephridia) type c (Fig. 7C). First and the second pair or sometimes all pairs of pharyngeal glands with dorsal connection, the glands in IV without ventral lobes, pairs in V and VI with ventral lobes, largest in VI. Chloragocytes from V, brown in vivo. Dorsal vessel from XIX-XXIV, blood colourless. Midgut pars tumida not seen. Five pairs of preclitellar nephridia from $6 / 7$ to $10 / 11$, length ratio anteseptale : postseptale 1 : $1.5-2$, midventral origin of efferent duct. Coelomo-mucocytes type c, 20-40 $\mu \mathrm{m}$ long in vivo, nucleus well visible, lenticytes 6-10 $\mu \mathrm{m}$ long (Fig. 7E). Chylus cells between XIII-XVII, occupying 4-5 segments. Seminal vesicle large in IX-XII, occupying 3 segments. Sperm funnels cylindrical (Figs. 7B, 8D-E), about 300-550 $\mu \mathrm{m}$ long and 110-270 $\mu \mathrm{m}$ wide (in vivo), 1.5-2 times as long as wide. In fixed specimens the length of funnels are $260-370 \mu \mathrm{m}$. Collar distinct, narrower than funnel body. Spermatozoa long but often difficult to measure accurately in the seminal vesicle, $600-1000 \mu \mathrm{m}$ long in vivo (in two specimens), but only 500-700 $\mu \mathrm{m}$ in the fixed specimens (in four specimens), heads 70-110 $\mu \mathrm{m}$ long in vivo (40-55 $\mu \mathrm{m}$ fixed). 
Diameter of sperm ducts $10 \mu \mathrm{m}$ (fixed). Male copulatory organs about $150 \mu \mathrm{m}$ long, $110 \mu \mathrm{m}$ wide, and $75 \mu \mathrm{m}$ high (fixed), the bursal slits y-shaped, the longer stem about $44 \mu \mathrm{m}$ long the shorter stems $22 \mu \mathrm{m}$ long. Subneural glands absent. Spermathecae (Figs 7D, 8F-G): one ectal gland at the ectal orifice (50-80 $\mu \mathrm{m}$ long), ectal ducts longer than body diameter, up to twice as long as body diameter, about $600-1000 \mu \mathrm{m}$ long, 30-35 $\mu \mathrm{m}$ wide in fixed specimens, proximally projecting into the ampullae, ental bulb 50-60 $\mu \mathrm{m}$ wide, canal 6-7 $\mu \mathrm{m}$ wide, not widened. Ampullae spherical (diameter about $100 \mu \mathrm{m}$ ) with two large ear- or bean-shaped, thin walled diverticula. Sperm mostly arranged in a ring in distal part of ampulla, also filling out lumina of diverticula, so that these are dark brown in transmitted light, as in F. phaeostri-
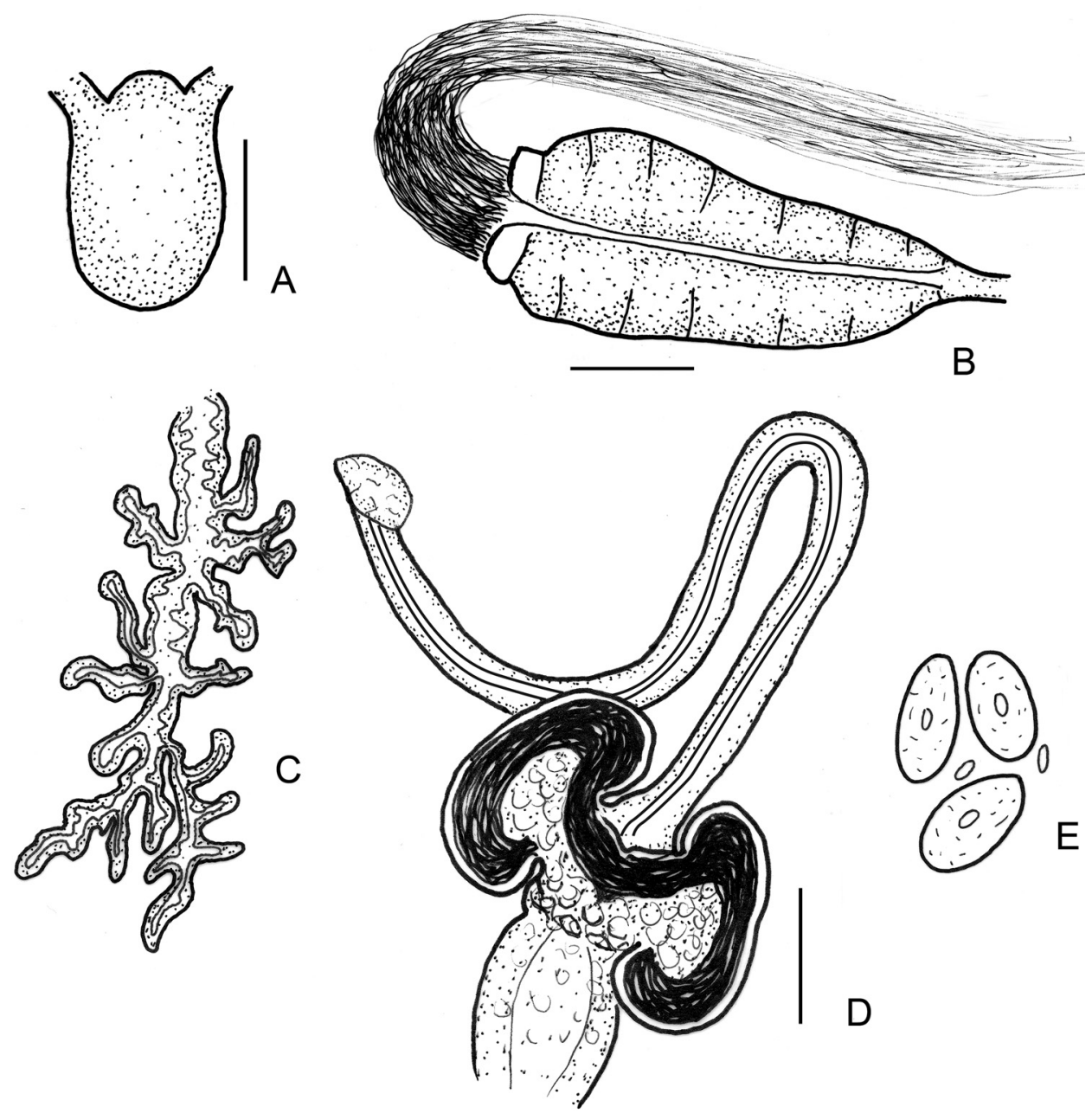

Fig. 7. Fridericia longiducta sp. $\mathrm{n} .: \mathrm{A}=$ brain, $\mathrm{B}=$ sperm funnel, $\mathrm{C}=$ oesophageal appendage, $\mathrm{D}=$ spermatheca, $\mathrm{E}=$ coelomocytes (all figures were made from living specimens, scale bares $\mathrm{A}-\mathrm{D}=100 \mu \mathrm{m}, \mathrm{E}=50 \mu \mathrm{m})$ 
ata sp.n. The length of diverticula 140-200 $\mu \mathrm{m}$ in vivo and 100-160 $\mu \mathrm{m}$ in the fixed specimens. Ampullae open separately into oesophagus. One-three mature egg at a time.

Distribution and habitat - Known only from two localities in the floodplain of Dráva river in the Danube-Dráva National Park: Bükkhát Forest Reserve, riverine oak-elm-ash woodlands, and alder and ash swamp woodlands near to village Kisszentmárton, Hungary.
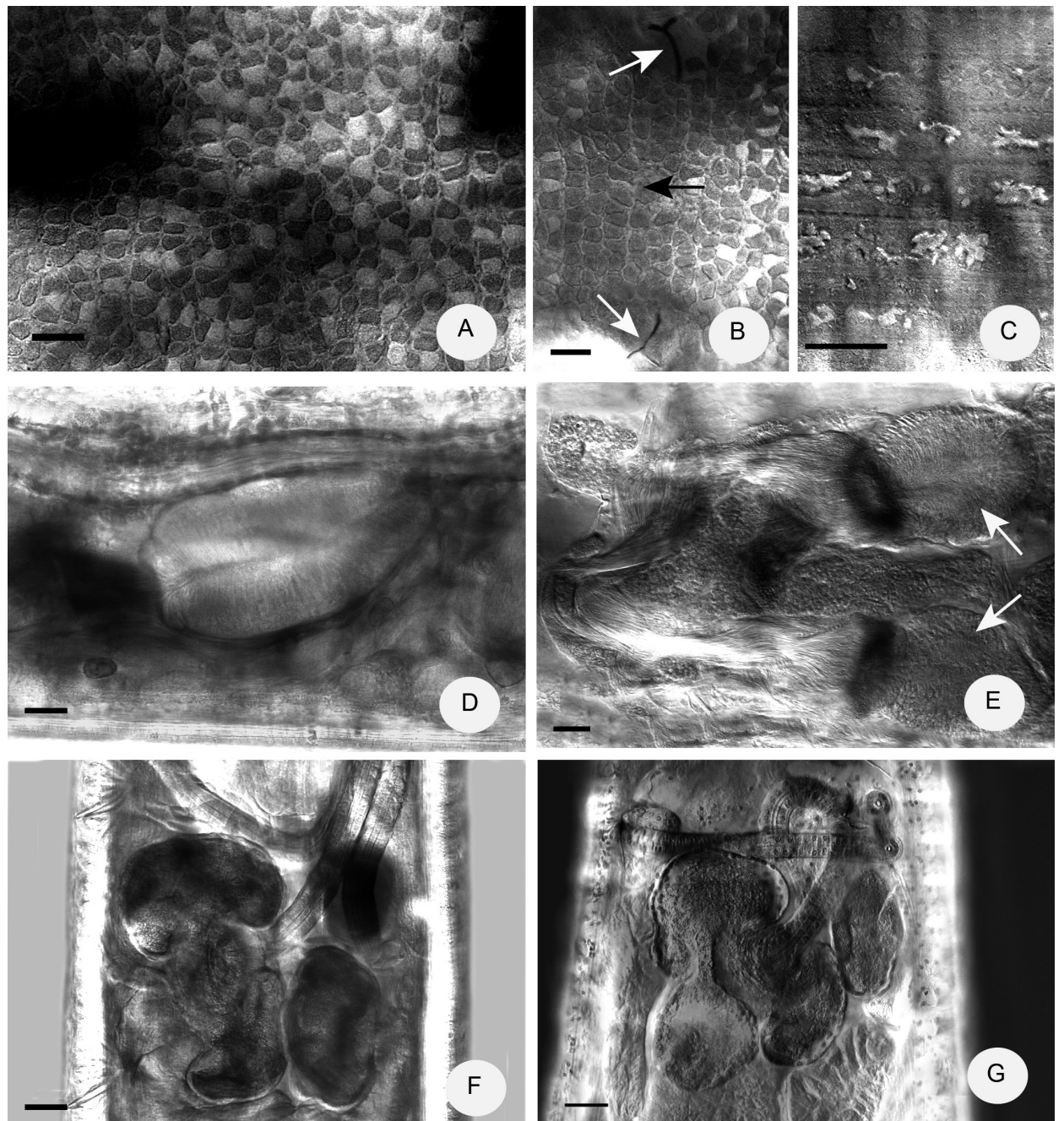

Fig. 8. Micrograph of Fridericia longiducta sp. n.: A = clitellar gland cells dorsally, B = clitellar glands ventrally (bursal slits marked with white arrows, between slits only granulocytes in rows marked with black arrow), $\mathrm{C}=$ epidermal gland cells in transversal rows, $\mathrm{D}-\mathrm{E}=$ sperm funnels, $\mathrm{F}-\mathrm{G}=$ spermathecae. (A-F in vivo, $\mathrm{G}$ fixed, stained holotypus; scale bars $=50 \mu \mathrm{m}$ ) 
Differential diagnosis - Five Fridericia species have similar spermathecae with two ear- or bean-shaped sessile spermathecal diverticula and separate connections with the oesophagus (four of them listed in Dózsa-Farkas 2009, tab. 6): F. magna Friend, 1899; F. strenua Rota, 1995; F. auritoides Schmelz, 2003; F. aurita Issel, 1905 and F. phaeostriata sp. n. The main differences are as follows: in F. aurita spermatozoa are of similar length, but the sperm funnel is longer (as long as or longer than body diameter vs. about half as long as body diameter), the spermathecal ectal duct is shorter and the ectal gland is absent (Issel 1905). In F.auritoides the best characteristic feature are the additional ventral lobes of pharyngeal glands in VII, absent in F. longiducta, moreover it has subneural glands, chylus cells in XVIII-XIX occupying 1.5-2 segments (between XIII-XVII occupying 4-5 segments in the new species) (Schmelz 2003). F. strenua has more chaetae (8) (Rota 1995). F. magna is longer (30-50 mm, 70-96 segments), the clitellum is saddle-shaped, and the blood is reddish (FrIEND 1899). Finally, F. longiducta sp. n. differs from the F. phaeostriata sp. n. by its size (17-23.5 mm long and 600-700 $\mu \mathrm{m}$ wide in vivo), the very long spermathecal duct (longer than body diameter), and the presence of only one ectal gland.

\section{Cernosvitoviella buekkhati Dózsa-Farkas, sp. n.}

(Figs 9-10)

Type material - Holotype C3 slide No.866, adult stained whole mounted specimen. Type locality: Páprád, Bükkhát Forest Reserve, 4552'19.4”N, 1800'47.4" E, 109 m a.s.l., riverine oak-elm-ash woodlands, deeper humid area, leg. Dózsa-Farkas, K., Ortmann-Ajkai, A \& Farkas, J., 28. 03. 2011.

Paratypes (in total 3 specimens): P 102.1-102.3, slides No. 864, 865, 867 three stained specimens, from type locality, leg. Dózsa-Farkas, K., Ortmann-Ajkai, A \& Farkas, J., 28. 03. 2011.

Deposited in the collection of Department of Systematic Zoology and Ecology, Eötvös Loránd University, Budapest.

Etymology - Named after the type locality.

Diagnosis - The new species can be recognized by the following combination of characters: (1) small size (2-2.5 mm, in vivo), segments 16-21; (2) maximum 4-7 sigmoid and nodulate chaetae per bundle; (3) clitellum only laterally; (4) two or three preclitellar nephridia; (5) coelomocytes spindleshaped, mostly black in transmittent light; (6) $2+2$ pharyngeal glands, the primary pairs more or less with dorsal connection; (6) sperm funnel cylindrical, approximately half as long as body diameter, collar as wide as funnel body (in vivo); (7) sperm ducts not widened, male pores surrounded by loose gland cells; (8) spermathecae free in $\mathrm{V}$, ectal duct ( $70-80 \mu \mathrm{m}$ long, $6-8 \mu \mathrm{m}$ wide), the ampulla twice as wide as duct; one conspicuous sessile ectal gland surrounding the ectal part of ectal duct. 


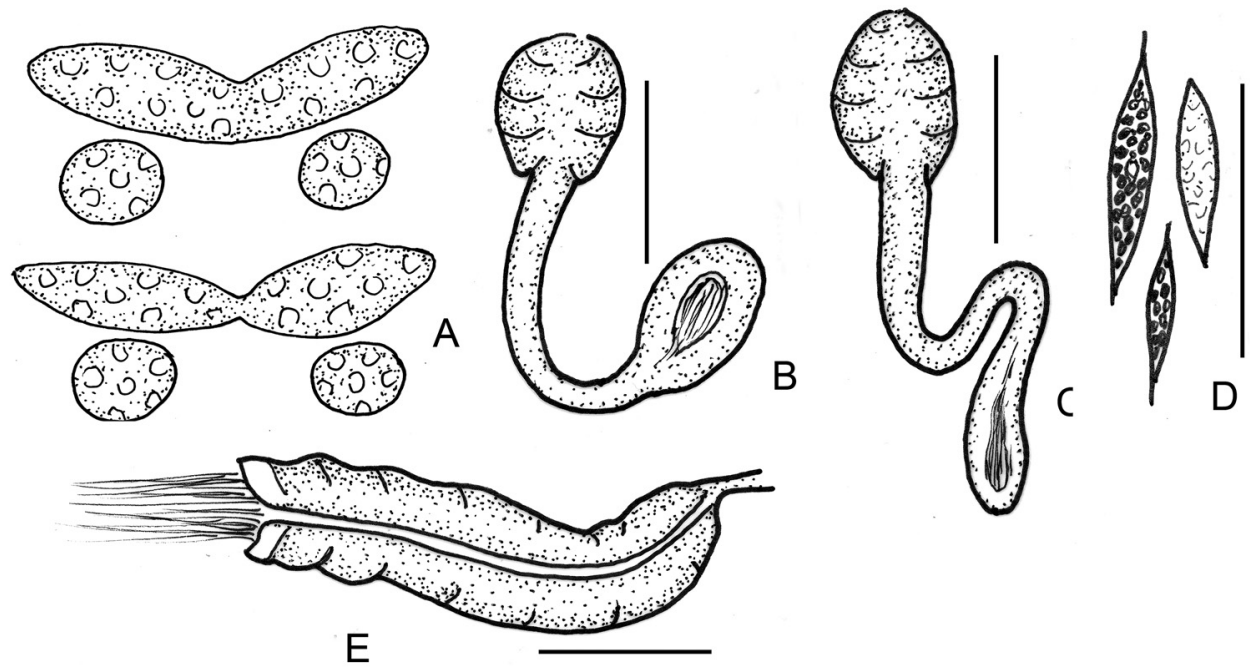

Fig. 9. Cernosvitoviella buekkhati sp. n. A = pharyngeal glans (schematic), B-C= spermathecae, $\mathrm{D}=$ coelomocytes, $\mathrm{E}=$ sperm funnel (all figures were made from living specimens, scale bares $B, C, E=50 \mu \mathrm{m}, \mathrm{D}=25 \mu \mathrm{m}$ )

Description - Holotype $1.05 \mathrm{~mm}$ long, $190 \mu \mathrm{m}$ wide at VIII and $210 \mu \mathrm{m}$ at clitellum (fixed), segments 16 . Body length of the paratypes $2-2.5 \mathrm{~mm}$, width $180-200 \mu \mathrm{m}$ at VIII and $200-240 \mu \mathrm{m}$ at the clitellum (in vivo). Length of fixed specimens 1.1-1.26 mm, width 150-190 $\mu \mathrm{m}$ at VIII and 180-210 $\mu \mathrm{m}$ at the clitellum. Segments 16-21. Chaetae slender, sigmoid with nodulus, about 4-6 (7) per bundle, maximum length about 20-25 $\mu \mathrm{m}$. Head pore were not detectable. Dorsal pores absent. Epidermal gland cells undistinguishable. Clitellum in XII-1/2XIII, gland cells only laterally, more granulocytes than hyalocytes present, cells about $15 \times 10 \mu \mathrm{m}$ wide. Thickness of body wall about $5 \mu \mathrm{m}$ in fixed specimens, cuticle thin. Brain deeply incised posteriorly, about $70 \mu \mathrm{m}$ long (fixed) and 1.5 times longer than wide (Fig. 10A).
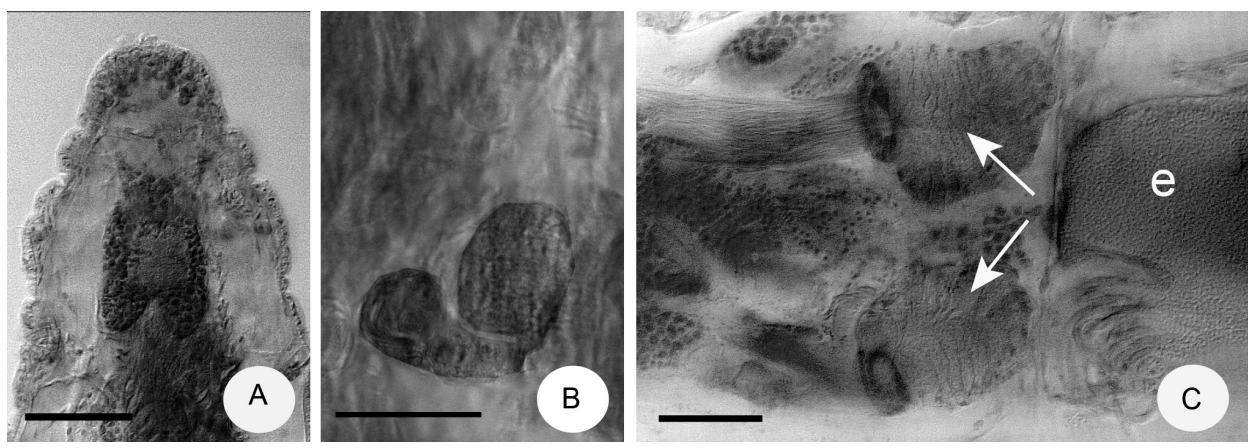

Fig. 10. Micrograph of Cernosvitoviella buekkhati sp. $\mathrm{n} .: \mathrm{A}=$ brain, $\mathrm{B}=$ spermatheca; $\mathrm{C}=$ sperm funnels (marked with arrows, $\mathrm{e}=\mathrm{egg}$ ). (All fixed, stained, $\mathrm{A}, \mathrm{C}=$ scale bars $=50 \mu \mathrm{m}$, $\mathrm{B}=$ scale bar $25 \mu \mathrm{m})$ 
Oesophageal appendages and intestinal diverticula absent. Pharyngeal glands two primary pairs in IV and $\mathrm{V}$, more or less with dorsal connection and two secondary pairs in $\mathrm{V}$ and VI (Fig. 9A) Dorsal vessel from XII, blood pale. Three or two preclitellar nephridia in 6/7-7/8 and 9/10 (or 6/7 and 7/8), single, i.e. unpaired, of the typical Cernosvitoviella-type. Coelomocytes (Fig. 9D) spindle-shaped with dark granula (dark in transmittent light) but some of them pale, length $17-25 \mu \mathrm{m}$ in vivo. Seminal vesicle absent. Sperm funnels cylindrical (Fig. 9E), about 110-135 $\mu \mathrm{m}$ long and 24-27 $\mu \mathrm{m}$ wide in vivo. Funnel in fixed specimens (Fig. 10C) about $50 \mu \mathrm{m}$ long and $20 \mu \mathrm{m}$. Collar as wide as funnel body. Spermatozoa about $52 \mu \mathrm{m}$ long, heads $19 \mu \mathrm{m}$ in vivo. Diameter of sperm ducts $10 \mu \mathrm{m}$ wide (fixed). Male pores surrounded by loose gland cells. Width of this opening with glands about 20-25 $\mu \mathrm{m}$ (fixed). Subneural glands absent. Spermathecae (Figs 9B-C, 10B) free, not attached to oesophagus, consisting of ectal duct (70-80 $\mu \mathrm{m}$ long, 6-8 $\mu \mathrm{m}$ wide) and ampulla about twice as wide as duct, only in V; (in one case extending into VI, at the orifice of the ectal duct one large, sessile ectal gland surrounding the ectal part of the duct, length about $38 \mu \mathrm{m}$ in vivo. In fixed specimens ectal ducts $40-60 \mu \mathrm{m}$ long, 8-12 $\mu \mathrm{m}$ wide, the ampullae 12-15 $\mu \mathrm{m}$ wide, diameter of ectal gland 20-32 $\mu \mathrm{m}$. One mature egg at a time.

Distribution and habitat - Only type locality.

Differential diagnosis - C. buekkhati sp. n. is clearly distinguished from all hitherto described Cernosvitoviella species by the large gland at the spermathecal ectal pore.

\section{DISCUSSION}

An overview of the enchytraeid fauna in the Danube-Dráva National Park is given in Table 1 and Appendix. Added are also two non-enchytraeid "microdrile" annelids, the oligochaete Rhyacodrilus falciformis (Rhyacodrilinae, Tubificidae), and the polychaete Hrabeiella periglandulata (Hrabeiellidae, Aphanoneura), commonly found in terrestrial habitats (DózsA-FARKAs \& Schlaghamersky 2013). Truly aquatic microdrile oligochaete species were not identified and are not listed. The enchytraeid fauna (49 species of 14 genera) of this area is quite diverse, and consists mostly of species typical for the Hungarian or wider Central European fauna (DózsA-FARKAs 2013, Schmelz \& Collado 2010). From the aspect of species number of the investigated areas, the Bükkhát Forest Reserve near to Páprád (riverine oak-elm-ash woodlands) showed the largest value with 29 species, furthermore the deeper humid area of these woodlands presented the highest species number with 36 species. All of the three new Fridericia species (F. connatiformis sp. n., Fridericia longiducta sp. n., F. phaeostriata sp. n.) occurred in the latter area. Cernosvitoviella buekkhati sp. n. was found exclusively in that habitat type. We have to notice that this latter species presumably has a very narrow geographical distribution, and it could be rare (and maybe endemic), based on the fact that we found all four specimens in only one sample, and that this species did not occur in any 
other of the subsequent samplings over a period of several years. Fridericia longiducta sp. $\mathrm{n}$. also seems to be a species with a narrow geographical range. Until now we have found it only in the humid habitats of the investigated parts of the Danube-Dráva National Park. Contrarily, the other two new Fridericia species occupy a broader area in Hungary. F. connatiformis sp. n. was found not only in the Dráva floodplain but also near by the Tisza river, and in the Mátra Mountains and the Örség area, which represent distant locations within Hungary (several hundreds of kilometres far from each other). In Hungary, the F. phaeostriata sp. n. has been found at 3 locations (floodplain of Dráva river, Köszegi and Villányi Mountains), always in woodland habitats. The Barcs Nature Conservation Area with dry shrub vegetation with Juniperus communis showed the expected low species richness with 3 species (Achaeta affinis, Chamaedrilus sphagnetorum sensu lato, Enchytronia parva), but the fringe of the pedunculate oak woodland near by the latter presented 15 species (all of them ubiquitous in Hungary), due to the more favourable conditions of humidity and the leaf-litter. We wrote the term of sensu lato in the case of the Chamedrilus sphagnetorum because the former species Cognettia sphagnetorum (Vejdovský, 1878) has recently been subdivided into 4 different species, two of them new (MArTinsson et al. 2014), and the individuals that we investigated formerly were juveniles, hence we did not fix them, so it could not be possible to determinate posteriorly their status accordingly to the present classification. Besides the above mentioned results, the presence of Enchytronia baloghi is also interesting, because formerly this species was described from Moroccan collections (Dózsa-Farkas 1988). It is possible that this species is present in other parts of Europe, too, which is supported by its presence in Transylvania (Boros \& Dózsa-Farkas 2014).

Acknowledgements - Many thanks to Dr. János Farkas, Dr. Gergely Boros, Dr. Zoltán Tóth, Ferenc Hock for assistance in sampling. This research was financed by the Hungarian Scientific Research Found (OTKA 49635 and K77999). We thank our reviewers for all the suggestions and corrections and Emma Sherlock (Natural History Museum, London) for polishing the English of the manuscript.

\section{REFERENCES}

Boros, G. \& Dózsa-Farkas, K. (2014) The enchytraeid fauna of Transylvania, Romania. 11th International Symposium on Enchytraeidae. Osnabrück, Germany, July 25-27, p. 15.

Bretscher, K. (1902) Beobachtungen über die Oligochaeten der Schweiz VI. Folge. Revue Suisse de Zoologie 3: 369-426. 
Dózsa-Farkas, K. (1988) Eine neue Enchytronia-Art aus Marokko. Opuscula Zoologica 23: 149-151.

Dózsa-Farkas, K. (2009) Review of the Fridericia species (Oligochaeta: Enchytraeidae) possessing two spermathecal diverticula and description a new species. Journal of Natural History 43(17-18): 1043-1065. doi: 10.1080/00222930902767441

Dózsa-Farkas, K. (2013) New Fridericia species (Oligochaeta: Enchytraeidae) from Vértes Mountains of Hungary. Acta Zoologica Academiae Scientiarum Hungaricae 59(4): 401-421.

Dózsa-Farkas, K. \& Schlaghamersky, J. (2013) Hrabeiella periglandulata (Annelida: "Polychaeta") - Do apparent differences in chaetal ultrastructure indicate the existence of several species in Europe? Acta Zoologica Academiae Scientiarum Hungaricae 59(2): 143-156.

DövÉNYI, Z. (2010) Magyarország kistájainak katasztere. MTA Földrajztudományi Kutatóintézet, Budapest, 876 pp.

European Commission (2007) Council Directive 92/43/EEC of 21 May 1992 on the conservation of natural habitats and of wild fauna and flora. http://ec.europa.eu/environment/ nature/legislation/habitatsdirective/index_en.htm [visited at 13.04.2015]

FAO-UNESCO (1997) Soil map of the world. Technical paper 20, ISRIC, Wageningen, $146 \mathrm{pp}$. Friend, H. (1899) New British annelids. Zoologist 3: 262-265.

Juhász, M., Szerdahelyi, T. \& Szollát, Gy. (1985) Újabb adatok a Barcsi Tájvédelmi Körzet flórájához. (New data to the flora of the Preservation area of Barcs, Hungary). Dunántúli Dolgozatok Természettudományok Sorozat 5: 35-51.

Issel, R. (1905) Un enchytraeide ad ampolla spermatecale unica. Atti della Societa dei Naturalisti e Matematici di Modena 7: 77-79.

Martinson, S., Rota, E. \& Erséus, C. (2015) Revision of Cognettia (Clitellata, Enchytraeidae): re-establishment of Chamaedrilus and description of cryptic species in the sphagnetorum complex. Systematics and Biodiversity 13(3): 257-277. doi: 10.1080/ 14772000.2014.986555

Molnár, Zs., Bartha, S., Seregélyes, T., Illyés, E., TímÁr, G., Horváth, F., Révész, A., Kun, A., Botta-Dukát, Z., Bölöni, J., Biró, M., Bodonczi, L., DeÁk, J.Á., Fogarasi, P., Horváth, A., Isépy, I., Karas, L., Kecskés, F., Molnár, Cs., Ortmann-Ajkai, A. \& Rév, Sz. (2007) A grid-based, satellite-image supported, multi-attributed vegetation mapping method (MÉTA). Folia Geobotanica 42: 225-247. doi: 10.1007/BF02806465

O'Connor, F. B. (1962) The extraction of Enchytraeidae from soil. Pp. 279-285. In: Murphy, P. W. (ed.): Progress in soil zoology. Butterworths Publishers, London.

Ortmann-AjKaI, A (1997) Égerlápok Kisszentmárton határában. Kitaibelia 2(2): 302-303.

Ortmann-AjkaI A. (1998) Vegetation mapping as a base of botanical GIS applications II. Vegetation map of Vajszló forest (SW Hungary). Acta Botanica Hungarica, 41(1-4): 193-227.

Ortmann-Ajkai, A. \& Horváth, F. (2010) „A Mecsek hegység déli síkja”: A Drávamentisíkság vegetációjának áttekintése a MÉTA adatbázis alapján. Dunántúli Dolgozatok Természettudományi Sorozat 12: 266-280.

Ortmann-Ajkai, A., Csicsek, G., Bölöni, J. \& Horváth, F. (2012) Merre tart a Bükkhát erdőrezervátum? Természetvédelmi Közlemények 18: 415-424.

RotA, E. (1995) Italian Enchytraeidae (Oligochaeta). I. Bollettino di Zoologia 62: 183-231. doi: $10.1080 / 11250009509356067$

Schlaghamerskŕ, J. (2007) Fridericia brunensis sp. n. (Clitellata: Enchytraeidae) - a new European enchytraeid species similar to F. monochaeta Rota, 1995. In: ScHLAGHA- 
MERSKÝ, J. (ed.) Folia Facultatis Scientiarum Naturalium Universitatis Masarykianae Brunensis, biologia 110, Newsletter on Enchytraeidae No. 10: Proceeding of the 7th International Symposium on Enchytraeidae, May 25-28, 2006. Masaryk University Brno, Czech Republic. Brno (Czech Republic): Masaryk University. pp. 53-65.

Schmelz, R. M. (2003) Taxonomy of Fridericia (Oligochaeta, Enchytraeidae). Revision of species with morphological and biochemical methods. Abhandlungen des Naturwissenschaftlichen Vereins in Hamburg 38: 1-414. + 73 Figs.

Schmelz, R. M. \& Collado, R. (2010) A guide to European terrestrial and freshwater species of Enchytraeidae (Oligochaeta). Soil Organisms 82(1): 1-176.

Revised version received April 20, 2015, accepted July 18, 2015, published October 19, 2015

\section{APPENDIX}

Investigated localities, habitats, sampling date with the recorded species.

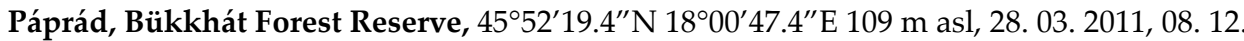
2012, 13. 11. 2013, november 2014.

Riverine oak-elm-ash woodlands 29 species: Achaeta sp., Achaeta eiseni, Buchholzia appendiculata, Cernosvitoviella buekkhati sp. n., Enchytraeus buchholzi sensu lato, E. bulbosus, E. christenseni, Enchytronia christenseni, En. parva, Fridericia longiducta sp. n., F. phaeostriata sp. n., F. benti, F. bisetosa, F. bulboides, F. connata, F. connatiformis sp. n., F. dura, F. galba/2, F. paroniana, F. perrieri, F. ratzeli, F. sohleni, F. miraflores, Henlea nasuta, H. perpusilla, H. ventriculosa, Marionina argentea sensu lato, M. simillima, Stercutus niveus.

Deeper humid area in the same forest 38 species: Achaeta sp., Achaeta affinis, Achaeta eiseni, A. pannonica, Buchholzia appendiculata, Cernosvitoviella minor, Cernosvitoviella buekkhati sp. n., Chamaedrilus glandulosus, Enchytraeus buchholzi sensu lato, E. bulbosus, E. christenseni, Enchytronia christenseni, En. parva, En. baloghi, Fridericia longiducta sp. n, F. phaeostriata sp. n., F. benti, F. bisetosa, F. bulboides, F. connata, F. connatiformis sp. n., F. deformis, F. dura, F. galba/1-2, F. nemoralis, F. paroniana, F. perrieri, F. ratzeli, F. sohleni, F. schmelzi, Globolidrilus riparius, Hemifridericia parva, Henlea nasuta, H. ventriculosa, Marionina argentea sensu lato, M. simillima, Mesenchytraeus pelicensis, Stercutus niveus + Hrabeiella periglandulata, Rhyacodrilus falciformis.

Decaying tree trunks 7 species: Buchholzia appendiculata, Bryodrilus ehlersi, Enchytraeus buchholzi sensu lato, F. phaeostriata sp. n., F. dura, Henlea nasuta, Mesenchytraeus pelicensis.

Páprád, Bükkhát Forest Reserve 4552'22.4"N 1800'59.7"E 112m asl, 28. 03. 2011.

Lowland pedunculate oak-hornbeam woodlands 18 species: Achaeta sp, Buchholzia appendiculata, Chamaedrilus glandulosus, Enchytraeus buchholzi sensu lato, E. bulbosus, $\boldsymbol{F}$. phaeostriata sp. n., F. bisetosa, F. dura, F. isseli, F. lacii, F. paroniana, F. perrieri, F. ratzeli, F. schmelzi, F. miraflores, H. perpusilla, Marionina argentea sensu lato, Stercutus niveus.

In lowland pedunculate oak-hornbeam woodlands under Ruscus aculeatus shrubs $45^{\circ} 52^{\prime}$ $35.2^{\prime \prime} \mathrm{N} 18^{\circ} 00^{\prime} 41.3^{\prime \prime} \mathrm{E} 127 \mathrm{~m}$ asl, 28. 03. 2011. 17 species: Achaeta sp. Buchholzia appendiculata, Enchytraeus buchholzi sensu lato, E. christenseni E. lacteus, E. coronatus, Enchytronia parva, F. phaeostriata sp. n., F. connata, F. connatiformis sp. n, F. galba/2, F. nemoralis, F. perrieri, F. ratzeli, H. perpusilla, Marionina argentea sensu lato, Stercutus niveus). 
In Lowland pedunculate oak-hornbeam woodlands. Decaying tree trunks 6 species: Bryodrilus ehlersi, Buchholzia appendiculata, Fridericia phaeostriata sp. n., Henlea nasuta, Mesenchytraeus pelicensis, Stercutus niveus.

Kisszentmárton Alder and ash swamp woodlands 4549'18.6" $\mathrm{N} 18^{\circ} 01^{\prime} 09.3^{\prime \prime} \mathrm{E} 94 \mathrm{~m}$ asl, 28. 03. 2011.

Alder leaf-litter and soil. 7 species: Buchholzia appendiculata, Enchytraeus buchholzi sensu lato, Fridericia longiducta sp. n, F. benti, F. bulboides, F. ratzeli, Hemifridericia parva.

Muddy under the alder trees. 4 species: Buchholzia fallax, Chamaedrilus glandulosus, Fridericia longiducta sp. n., Marionina argentea sensu lato.

Roots of Carex acutiformis from water. 2 species: Marionina communis, Henlea nasuta+ many Naididae.

Between Sellye és Bogdása. Meadow (with young Quercus plantation) $45^{\circ} 52^{\prime} 24.6^{\prime \prime} \mathrm{N} 17^{\circ}$ 48'01.1"E $104 \mathrm{~m}$ asl, 28. 03. 2011. 7 species: Enchytraeus buchholzi sensu lato, F. connata, F. connatiformis sp. $\mathbf{n}, F$. schmelzi, Henlea perpusilla, H. ventriculosa, Marionina simillima.

Between Lakócsa and Potony. Lowland pedunculate oak-hornbeam woodlands, $45^{\circ} 54^{\prime}$ 47.3"N 17040'20.4"E 120 m asl, 28. 03. 2011. 8 species: Buchholzia fallax, Chamaedrilus glandulosus, Enchytraeus buchholzi sensu lato, Fridericia phaeostriata sp. n., F. benti, F. bisetosa, F. galba/1-2, Marionina argentea sensu lato.

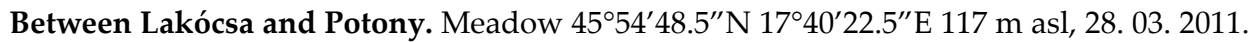
3 species: Enchytraeus coronatus, Fridericia bulboides, F. paroniana.

Near Lakocsa village. Mesotrophic wet meadows $45^{\circ} 54^{\prime} 49.9^{\prime \prime} \mathrm{N} 17^{\circ} 41^{\prime} 38.9^{\prime \prime} 109 \mathrm{~m}$ asl, 28. 03. 2011. 11 species: Buchholzia fallax, Cernosvitoviella minor, Enchytraeus buchholzi sensu lato, E. christenseni, Enchytronia christenseni, Fridericia bulboides, F. lacii, F. perrieri, Globulidrilus riparius, Marionina argentea sensu lato, M. communis.

Near Darány village. Old pedunculate oak woodland with some Pinus silvestris $45^{\circ} 58^{\prime}$ 08.02"N 17²5'01.1"E $132 \mathrm{~m}$ asl, 13. 11. 2013. 10 species: Achaeta affinis, Buchholzia appendiculata, Enchytraeus buchholzi sensu lato, E. bulbosus, Enchytronia parva, Fridericia bisetosa, F. bulboides, F. paroniana, Hemifridericia parva, Marionina argentea sensu lato + Hrabeiella periglandulata.

Barcs Juniper Protected Area. Dry shrub vegetation with Juniperus communis $45^{\circ} 58^{\prime} 50.5^{\prime \prime} \mathrm{N}$ 17³4'37.2"E 123 m asl, 13. 11. 2013. 3 species: Achaeta affinis, Chamaedrilus sphagnetorum sensu lato, Enchytronia parva.

Near to the Protected Area. Pinus nigra plantation 45 $58^{\prime} 49.4^{\prime \prime} \mathrm{N} 17^{\circ} 32^{\prime} 87.6^{\prime \prime} \mathrm{E} 107 \mathrm{~m}$ asl, 13. 11. 2013. 2 species: Achaeta affinis, Enchytronia parva.

Fringe of the pedunculate oak woodland with Pteridium aquilinum. $45^{\circ} 58^{\prime} 29.6^{\prime \prime} \mathrm{N}$ 17²32'52.6”'E $107 \mathrm{~m}$ asl, 13. 11. 2013. 15 species: Achaeta affinis, Buchholzia appendiculata, Chamaedrilus glandulosus, Chamaedrilus sphagnetorum sensu lato, Enchytraeus buchholzi sensu lato, E. bulbosus, Enchytronia parva, Enchytronia sp., Fridericia bisetosa, F. bulboides, F. connata, F. dura, F. paroniana, Hemifridericia parva, Marionina argentea sensu lato. 